\title{
The Effect of Interval Run Training on Increasing VO2 Max on Futsal Player
}

\author{
Ahmad Nohrizal, Maruful Kahri, Shadiqin \\ Department of Sport Education and Health \\ Lambung Mangkurat University \\ Banjarmasin, Indonesia \\ ahmad_nohrizal@yahoo.co.id
}

\begin{abstract}
This study aims to determine the effect of interval running training on increasing VO2 Max on MAN Selat Tengah futsal Kapuas Regency. The research method used is the preexperiment design method. The population in this study was the futsal player MAN Selat Tengah Kapuas Regency, who participated in futsal extracurricular totaling 30 people, while the sample of the study amounted to 20 people. The sampling technique uses purposive sampling. The results showed that the pretest variable increased VO2 Max in futsal players MAN Selat Tengah Kapuas Regency obtained an average of $13.1250 \mathrm{ml} / \mathrm{kg}$ $/$ min with a standard deviation $=\mathbf{5 . 8 6 5 5 0}$. Whereas the posttest variable increased VO2 Max on MAN futsal players in Selat Tengah Kapuas District obtained an average of 44.6100 with a standard deviation $=5.49937$. $T$ Test results obtained obtained $t$ count $=-8,739>t$ table $(23 ; 0,025)=2,093$, or with Sig. $(2$-tailed $)$ $=0,000$; it turns out that Sig. (2-tailed) <0.05 thus the tcount is significant. The conclusion is that there is an effect of interval running training on the increase in VO2 Max on MAN Selat Tengah futsal Kapuas Regency.
\end{abstract}

\section{Keywords: training, running, interval, VO2 Max}

\section{INTRODUCTION}

Futsal is a kind of football game played on a smaller field, played by two teams, each with 5 players [1]. A futsal player must have qualified physical endurance, so that the player has sufficient readiness to face each match and has the skills as a professional futsal player. Observations on the futsal championship in Kapuas Regency on October 10, 2015 to October 20, 2015 and during training, when playing players quickly experience fatigue, at the beginning of the game can still compensate for the opponent's game, but in the middle and towards the end of the game the player does not can compensate for the opponent's game. The results of these observations, researchers can analyze that the cause of the lack of ability to play futsal is the maximum oxygen volume or VO2 Max is not optimal when playing futsal, so it needs to be improved.

This condition occurs due to the low ability of trainers in making training programs is still ignored, that training to improve endurance has not been done properly, so that the impact on VO2 Max futsal players. Planning an exercise program must be carried out well organized, methodical, and scientific so that the coach can help athletes, especially the talented achieve the highest achievements [2]. The knowledge of the trainer in training also influences in doing an exercise program, as a trainer must be able to train properly and correctly, be able to expect good and appropriate training methods and materials in order to obtain optimal results. said There are four aspects of training that need to be considered and trained carefully by athletes, namely: physical, technical, tactic, and mental training [3]. Futsal play, a dominant physical component of aerobic endurance. Because a futsal player must play with high intensity and a long time, so the player must be able to maintain his aerobic endurance until the end of the game, so that futsal athletes must have good aerobic endurance. Many methods and forms of exercise that can be used to improve athlete's aerobic endurance, such as fartlek training, interval training, continuous run, cross country [4].

In training endurance (endurance) can also be trained through exercises. Two training systems that can guarantee an increase in endurance (endurance), namely fartlek and interval training [3]. Thus to increase the VO2 Max, it can be done with interval running exercises. Because VO2 Max is interconnected and has a dominant role in futsal, its influence on changes to VO2 Max needs to be revealed immediately. This is important because this type of interval running practice is easily done by anyone and the availability of ingredients does not require expensive equipment, but the benefits are very important to influence the increase in VO2 Max futsal players. As a solution to answer the problem, the effect of interval running training on increasing VO2 Max futsal players MAN Selat Tengah Kapuas Regency needs to be immediately assessed through an experimental study. The general objective is to determine the effect of treatment on the dependent variable namely VO2 Max futsal player MAN Selat Tengah Kapuas Regency. The sample criteria to be used are students who truly have mastered the basic techniques of playing futsal and following extracurricular activities and are often included in following futsal championships or matches. This is determined so that the effect of the treatment becomes clear VO2 Max futsal player MAN Selat Tengah Kapuas Regency.

\section{METHODOLOGY}

The research method used in this is the preexperiment design [5]. It is said pre-experiment design, because this research design is not an actual experimental study, or there are still external variables that influence the formation of the dependent variable. So the experimental results of the dependent variable are not solely influenced by the independent variable. This is possible because the sample was not randomly selected and there was no control variable. 
The design in this study used the One-Group PretestPosttes Design, which means that before the treatment was given there was a pretest, and after the treatment was given a post-testtest. From this the treatment results can be known to be more accurate, because they can compare with the conditions before being treated. The design of this study can be described as follows: $\mathrm{O} 1$ initial test, $\mathrm{O} 2$ treatment and final test [5].

The population in this study was the futsal player MAN Selat Tengah Kapuas Regency, who participated in futsal extracurricular totaling 30 people, while the sample of the study amounted to 20 people. The sampling technique uses purposive sampling.

\section{RESULTS AND DISCUSSION}

The results of the data obtained in the field: pretest data increase in VO2 Max futsal players in MAN Selat Tengah Kapuas Regency (X1) obtained an average of 37.1250 ; with the highest score of $47.10 \mathrm{ml} / \mathrm{kg} / \mathrm{min}$ and the lowest score of $28.70 \mathrm{ml} / \mathrm{kg} / \mathrm{min}$; 2) posttest data increase VO2 Max futsal players in MAN Selat Tengah Kapuas Regency obtained an average of 44.6100 seconds; with the highest score of $51.60 \mathrm{ml} / \mathrm{kg} / \mathrm{min}$ and the lowest score of $30.60 \mathrm{ml} / \mathrm{kg} / \mathrm{min}$. The data above shows that there is an increase in the average before treatment and the average after treatment, this shows that interval running exercises can increase the increase in VO2 Max futsal players in the MAN Selat Tengah Kapuas Regency.

Based on the results of statistical analysis with the ttest as presented in the table above as follows; 1) the results of the t-test analysis of pretest variables with posttest increase in VO2 Max futsal players in MAN Selat Tengah of Kapuas Regency, obtained tcount $=-8,739>$ ttable $(19 ; 0.025)=$ 2,093 , or with Sig. (2-tailed) =0,000; it turns out that Sig. (2tailed) $=0,000<0.05$ thus the tcount is significant. So it can be concluded that there is an effect of interval running training to increase VO2 Max futsal players in MAN Selat Tengah of Kapuas Regency.

In this study provides interval running training in accordance with the correct interval running training procedures that are guided by the principles of training, among others: 1) the principle of individualization, meaning that each athlete has different VO2 Max abilities, so in their application considering individual differences namely age from the sample; 2) the principle of specialization, meaning that the training program is specifically designed to improve the VO2 Max of futsal players by adjusting the energy system, namely aerobics; 3 ) the principle of exercise variation, meaning that in its application for 5 weeks or 17 meetings with a frequency of 4 times a week, which consists of four to six sets of 4 minute intervals and interspersed with 2 minute breaks. The form of training interval used is a short range training interval that is 50 meters apart; 4) the principle of overload, which is carried out within 5 weeks, for 17 meetings with a frequency of 4 times a week, by applying the intensity of $80-90 \%$. Before the exercise was given the VO2 Max test, the sample used in this study was students who took futsal extracurricular activities at MAN Selat Tengah Kapuas Regency. Then after being given interval training exercise for 5 weeks or 17 meetings with a frequency of 4 times a week, consisting of four to six sets of 4 minute intervals and interspersed with a break of 2 minutes. The form of training interval used is a short distance training interval that is a distance of 50 meters and applies the principles of training in interval running exercises, among others: 1) the principle of individualization; 2) the principle of specialization; 3) the principle of exercise variation; 4) the principle of overload and the final VO2 Max test is done, thus increasing VO2 max futsal players in the MAN Selat Tengah of Kapuas Regency to be better than before getting interval training exercises. And also strengthened after analyzing the results of the initial test results and the final test showed an increase in VO2 Max futsal players in the MAN Selat Tengah Kapuas Regency and the influence of interval training exercises to increase VO2 Max futsal players in the MAN Selat Tengah Kapuas Regency. So that this exercise can be applied in schools for example in extracurricular activities in schools to improve VO2 Max futsal players in MAN Selat Tengah Kapuas Regency.

Futsal games are the dominant physical condition component of aerobic endurance. Because a futsal player must play with high intensity and a long time, so the player must be able to maintain his aerobic endurance until the end of the game, so that futsal athletes must have good aerobic endurance. There are many methods and forms of exercise that can be used to improve athlete's aerobic endurance, so interval running is applied in this experiment so that the increase in VO2 Max futsal players in the Kapuas Regency Selat Tengah Kapuas Regency is better, so that in playing futsal players the SelatTengah Regency will be better by having a VO2 Max good or very good..

\section{CONCLUSION}

The conclusion of this study is based on data analysis, hypothesis testing and discussion that has been carried out in the previous chapter, that there is an effect of interval running training on the increase in VO2 Max on futsal players in MAN SelatTengah Kapuas District significantly.

\section{ACKNOWLEDGMENT}

We would like to be grateful to the Dean of Teacher Training and Education Faculty, Lambung Mangkurat University, who has supported us in the form of funding. Therefore we could join this International Conference.

\section{REFERENCES}

[1] L. Yudianto, Teknik Bermain Sepak Bola dan Futsal. Jakarta: Visi7, 2009.

[2] Harsono, Perencanaan Program Latihan, 2nd ed. Bandung: UPI Press, 2004.

[3] Harsono, Coaching dan Aspek-Aspek Psikologi dalam Coaching. Jakarta: Tambak Utama, 1988.

[4] P. Andriyana, "Peningkatan Daya Tahan Aerobik Melalui Latihan Fartlek Dan Interval Training," Universitas Pendidikan Indonesia, 2015.

[5] Sugiyono, Metode Penelitian Kombinasi (Mixed Methods). Bandung: Alfabeta, 2014. 